\title{
Analysis of Income and Marketing Efficiency of Gouramy in Yeh Embang Kangin Jembrana Village
}

\author{
I Wayan Sudana \\ Functional Analyst of Fishery Products Market Intermediate \\ Department of Marine and Fisheries of Bali Province \\ Email: sedanaserasi@gmail.com
}

\begin{abstract}
Gouramy is one of the freshwater fisheries commodities that has good prospects to be developed, the price never goes down and trends to increase because the market demand for this commodity is quite high. This study was conducted to determine the pattern of gouramy marketing channels, the number of margins, farmer shares, and marketing efficiency in farmer groups in Yeh Embang Kangin Village in 2019. The data used are qualitative and quantitative, while based on their sources the primary and secondary data collected with an interview and documentation methods for further analysis with descriptive analysis techniques with quantitative approaches. The results showed that the marketing of gouramy in Yeh Embang Kangin Village had the same marketing pattern, from farmers to collectors to retailers to consumers. The total margin of Rp. 12,000/ $\mathrm{kg}$ and 73.3\% farmer share. And the value of farmer share is greater than the total margin. Based on the calculation of marketing efficiency, marketing efficiency is obtained at $12.4 \%$ so that it can be said that marketing gouramy with the marketing pattern used is classified as efficient.
\end{abstract}

Keywords: Marketing channels, marketing margins, farmer share, and marketing efficiency

\section{Introduction}

Gouramy is a freshwater fish commodity that has good prospects for development because a freshwater fish commodity whose price has never decreased, even tends to increase. Compared to other types of freshwater fish, the maintenance period for gouramy is longer so that the availability of this fish is not as much as other freshwater fish. And this causes the price of carp to tend to increase and never experience a decrease and this affects the income of producers and marketing institutions involved in marketing gouramy.

The marketing of fishery products is a very important component in fishery business activities because it affects business continuity and the high and low income of fishery business actors. Good production results will be in vain because of low market prices or unsold market prices so that high production does not provide high income or profits if it cannot be marketed or without efficient marketing. According to [1] marketing activities aim to streamline the flow of goods or services from producers to consumers efficiently to create effective demand. The marketing of fishery products is usually carried out by intermediary traders both large and small scale. And forming a long chain where this long chain results in marketing costs because each intermediary trader wants to get a profit to cover the costs incurred. The number of marketing costs and profits obtained by intermediaries is a component of determining prices at the consumer level. And it will affect the price at the producer level, even suppressing the price at the producer level [2]. 
Producers are more often in the position of receiving prices because they do not have a strong bargaining position compared to intermediary traders. And makes marketing inefficient. The marketing system is considered efficient if it can make a fair share of the total price paid by consumers to all parties involved in marketing activities [3]. Therefore, in addition to margins and the number of marketing costs, another indicator to determine marketing efficiency in comparison. commodity prices at the producer level or the share received by the producer (farmer's share).

In the Bali region, the center for the development of gouramy cultivation is in Jembrana Regency and one of them is Yeh Embang Kangin Village. The gouramy harvest produced by local farmers is marketed to other districts, namely Denpasar, Tabanan, and Badung are in living conditions. Due to the distance between the producing area and the marketing place, the marketing of gouramy in Yeh Embang Kangin Village uses middlemen to form a marketing channel. The marketing channel plays an important role because the marketing channel is a way to convey products produced by producers to consumers. According to [4] marketing channels can overcome the time, place, and ownership gap that separates goods or services from the people who need or use them. And according to [5]. In the marketing channel, 3 groups are involved, namely producers, traders, intermediaries, and consumers.

Marketing efficiency is one aspect of marketing to increase the movement of goods from producers to consumers. In marketing efficiency, it will be seen that there are differences in prices received by producers to those paid by end consumers, as well as the feasibility of income received by producers for the commodities produced. Marketing activities of fishery products will go through several processes including collection, grouping, distribution including the selection of marketing channels where the accumulation of this process will incur costs. The lower the costs incurred by the marketing system, the more efficient it will be, the lower the marketing margins. Low marketing margins will increase producers' income as well as relatively cheap prices for consumers. According to [3] marketing is considered efficient if 2 things are fulfilled, namely being able to deliver producer results to consumers at the cheapest possible price and to provide a fair share of the total price paid by the latter to all parties involved in the production process. According to [6] an efficient marketing system will provide benefits for business actors involved in the production process to the final sales process. Marketing activities will run smoothly if supported by high consumer purchasing power and proper distribution. Long links will result in high marketing costs because each intermediary trader wants to get a profit to cover the marketing costs that have been incurred, which is a component in determining prices at the consumer level. So that it affects the price at the producer level because the purchasing power of consumers is still limited.

The marketing pattern of gouramy produced by farmers in Yeh Embang Kangin Village is sold to collector traders than to collectors who act as retailers and finally to consumers. Where the collector traders who come directly to the producers then deliver the products to retailers in the Denpasar, Tabanan, and Badung areas including restaurants, fishing ponds, and restaurants to form a marketing chain. According to [7] the shorter the marketing chain for an item, the lower the trading system costs, the lower the marketing margin, the lower the price paid by consumers, and the higher the price received by producers.

This research aims to analyze the marketing efficiency of gouramy produced by fish farmers in Yeh Embang Kangin Village, Mendoyo District, to analyze the marketing efficiency of gouramy and to determine the amount of profit received by each marketing actor, marketing margin, and farmer share obtained by farmers. 


\section{Research Methodology}

Research on income analysis and marketing efficiency of gouramy fish was conducted using a survey method in Yeh Embang Kangin Village, Mendoyo District, Buleleng Regency. The selection of the research location was carried out with the consideration that gouramy farmers in the Yeh Embang Kangin area are one of the carp producers in the Jembrana Regency. Data collection was carried out on 17 to 28 October 2019 which was carried out on purpose because the respondents had been doing gouramy cultivation and marketing since 1995. The object of the study was four groups of Gajah Mina gouramy farmers, traders, and retailers. The number of population and research sample size is shown in Table 1.

Table 1

Total population and research sample size

\begin{tabular}{lllcc}
\hline No & $\begin{array}{l}\text { Marketing } \\
\text { Institution }\end{array}$ & Location & Population & Sample \\
\hline 1 & Farmers & Yeh Embang Kangin & 10 & 4 \\
\hline 2 & Collecting Traders & Jembrana & 3 & 2 \\
\hline 3 & Retailing Traders & Denpasar, Tabanan, Badung, Karangasem & 8 & 4 \\
\hline & Source: The farmer groups and primary data processed, 2019 & &
\end{tabular}

The number of samples taken non-proportionally depends on the number and level of diversity of actors in each marketing agency involved. Collecting data in this study consisted of primary data and secondary data. Primary data were obtained through observation and interviews with respondents. Observation is a data collection technique by making a direct introduction to the object of research to make direct observations of the data source or information provider [8] while the interview is a process of verbal questioning to obtain information that is not obtained through direct observation [9]. Primary data collected includes the pattern of marketing channels, marketing costs, and income from farmers and intermediaries. Meanwhile, secondary data is in the form of data obtained from group leaders related to the number of farmers. Data obtained from primary data collection and secondary data from interviews with respondents then tabulated the data and displayed in table form. Furthermore, the data were analyzed using analysis methods including qualitative and quantitative data. The qualitative analysis explains descriptively the profit-sharing pattern of the anchovies caught in the producers and about the marketing channels of gouramy at the research location, while the qualitative analysis is to determine the marketing margin, farmer share, and marketing efficiency.

Data analysis methods include qualitative and quantitative analysis. The qualitative analysis explains descriptively the marketing channels of gouramy in the research location. And quantitative analysis is to determine the marketing margin, farmer's share, profit ratio, and marketing efficiency according to [8].

1. The amount of marketing margin is calculated using the formula:

$$
\mathrm{MP}=\mathrm{Pr}-\mathrm{Pf}
$$

For one level of merchant marketing margin is calculated by the formula:

$$
\mathrm{MP}=\mathrm{KP}+\mathrm{BP} \quad \mathrm{KP}=\mathrm{MP}-\mathrm{Bp} \quad \mathrm{BP}=\mathrm{MPKP}
$$


Information:

$$
\begin{array}{ll}
\text { MP } & =\text { Marketing Margin } \\
\mathrm{Pr} & =\text { Price at the retailer level } \\
\mathrm{Pf} & =\text { Price at farmer level } \\
\mathrm{KP} & =\text { Marketing Profits } \\
\mathrm{BP} & =\text { Marketing Costs }
\end{array}
$$

Decision-making criteria

a. Marketing margin is said to be efficient if the number is close to 0

b. The smaller the value of the marketing margin, the more efficient marketing is. Also, marketing can be said to be efficient if the price value received by farmers is greater and on the overall marketing margin.

2. To calculate the farmer's share, the price received by farmers is calculated using the formula [10] :

$$
\mathrm{fs}=\frac{P f}{\operatorname{Pr}} x 100 \%
$$

Information:

Fs $\quad=$ Share (share) of the price received by farmers

Pf $=$ Price at the farmer level

$\operatorname{Pr} \quad=$ Prices at the retail level

Marketing efficiency indicators can be measured by the following criteria [9]:

1. If the share received by farmers is greater and the share received by farmers is close to $100 \%$, then the marketing channel is categorized as efficient.

2. If the share of the price received by farmers is smaller and the share of the marketing margin is large, then the marketing channel can be categorized as inefficient.

3. To find out about marketing efficiency, the following formula can be used:

$$
\mathrm{Ep}=\frac{\text { marketing costs }}{\text { the value of the product being marketed }} \times 100 \%
$$

with decision-making criteria.
1. $0-33 \%=$ efficient
2. $34-67 \%=$ less efficient
3. $68-100 \%=$ inefficient

\section{Result and Discussion}

Gouramy fish produced by Yeh Embang farmers are only harvested when the fish are 300-400 grams/fish, where the maintenance period is $8-10$ months. There are 2 crops of carp carried out in this area, namely selection harvest and total harvest: 1 . Selection harvest only harvests carp that have reached the size adjusted to market demand, namely with a size of more than $300 \mathrm{~g} /$ head. While the rest of the harvest is maintained again, 2. The total harvest is carried out one to two months after the selection harvest is harvesting all the fish after the rest of the selection harvest because all the gouramy have reached the consumption size. 
Marketing of gouramy harvested by farmers Yeh Embang Kangin Jembrana is marketed at restaurants and fishing ponds in the Denpasar, Tabanan, Badung, and Karangasem areas, through intermediary traders or collectors who go directly to producers. The presence or role of wholesaler traders is very important because it is related to the certainty and continuity of purchases from farmers' crops. The cooperation between farmers and traders has been established for a long time. The existence of this cooperation is because they need each other to form a marketing channel.

According to [11] marketing channels are a series of interdependent organizations involved in the process of making a product or service ready for consumption. Where farmers are primary producers or sellers, selling to collectors is called primary buyers or secondary sellers and then sold to restaurants, fishing ponds, and retailers to be distributed to consumers as the last buyers [12]. Harvesting of gouramy is done after reaching the consumption size, which is in the range of 300 $400 \mathrm{~g} /$ fish. The harvest schedule is determined after an agreement between producers and traders is based on orders from consumers. To make it easier to harvest and reduce damage to the fish's body, harvest the gouramy using a net that is stretched on two sides of the pond. Where when harvesting the water level is lowered according to the height of the net, then the net that is stretched is pulled and pushed slowly to one edge of the pond so that the space for the fish is limited then the fish is caught or harvested directly accommodated in a plastic drum container provided by collectors as well transport container in a lying position. Where the holding capacity for each drum is $40 \mathrm{~kg}$ with a volume of water \pm 50 liters.

Transportation of gouramy uses a pick-up car with 6 plastic drums. So the transporting capacity of gouramy for the capacity in Denpasar, Tabanan, and Badung is an average of $250 \mathrm{~kg}$. The price of carp bought by collectors is Rp. 33,000 / kg then sold to retailers for Rp. 38,000/ kg then retailers sell it to consumers at an average price of $\mathrm{Rp} .45,000 / \mathrm{kg}$ in live condition.

For the marketing of gouramy to be mutually beneficial, both producers and traders of collectors make efforts to harvest shrimp in living conditions because they are by consumer demand. Efforts to mitigate risks to minimize mortality include harvesting, storage, and transportation. The effort made in the harvesting of gouramy is using people who have experience in harvesting gouramy from the local area at a harvest cost of Rp. 2,000 / kg, harvesting activities are carried out in the morning to avoid the scorching heat of the sun and ensure that the harvested fish are healthy and not sick.

\subsection{Marketing Channels Marketing}

Agencies play an important role and determine the formation of marketing channels where each marketing agency has a different function, causing profits and the incidence of different marketing costs in each marketing channel, such as the function of packaging, storage, and transportation [13]. According to [14], the length of the marketing channels that a commodity passes through depends on several factors, including:

a. The distance between producers and consumers

The farther the distance between producers and consumers, the longer the marketing channel will be

b. Quickly or not the product breaks down

If it's quick or easy, it requires a short and fast marketing channel.

c. Production Scale

If the production takes place in small sizes, the amount of product produced is also small. This right will be profitable if the producers go directly to the market. In such circumstances, the presence of intermediary traders is not required. 
Marketing channels have an important role in delivering production results to consumers. According to [15], a marketing channel is a channel used by producers to distribute goods to consumers. Due to the limited purchasing power of consumers in producing areas, the gouramy produced by farmers Yeh Embang Kangin is marketed to the regions, Denpasar, Tabanan, and Badung. There are differences in the distance and travel time and the marketing production volume of gouramy produced in Yeh Embang Kangin village, Jembrana Regency, involving intermediary traders or collecting traders to market carp to form a marketing channel. Where a marketing pattern of gouramy produced by farmers was found in Yeh Embang Kangin village, Jembrana Regency, namely farmers to collecting traders than to retailers than to consumers which are shown in the following chart.

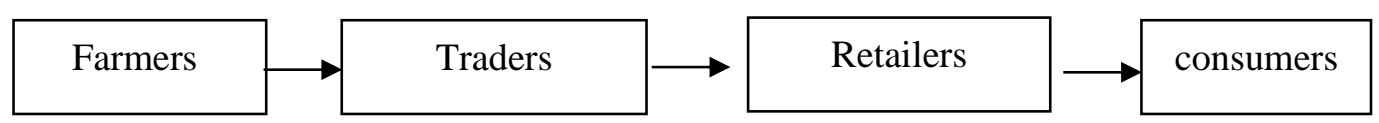

From this chart, it is known that the marketing channel for gouramy produced by farmers in Yeh Embang Kangin Village involves 2 intermediary traders, namely a collecting trader and a retailer which causes the marketing chain to become long. According to [7], the longer the trading system (the more marketing agencies involved), the bigger the marketing margins will cause the price received by producers to get smaller and show that the marketing channel is inefficient.

\subsection{Marketing}

Margin is the price difference that occurs at each marketing agency involved in the business of selling gouramy. According to [16], to determine the marketing margin, data is needed that includes fish prices, costs incurred, and the profits earned by traders. Marketing margin is the price difference between what must be paid to producers and the price paid by consumers. The marketing margin is determined by the number of marketing costs and the profits of each marketing agency. From the observations during the research costs that arise in marketing gouramy include transportation costs and harvest costs. Marketing costs, margins, farmer share, and profits of each institution can be seen in Table 2.

Table 2

Marketing costs, margins, farmer share, and profits of each institution

\begin{tabular}{|c|c|c|c|}
\hline Category & Cost Criteria & Margin & Farmer Share \\
\hline 1. Farmer & $\begin{array}{l}\text { Selling price }: 33,000 \\
\text { Production costs : } 16,750 \\
\text { Profit : } \quad 16,250\end{array}$ & & $73.3 \%$ \\
\hline 2. Collecting traders & $\begin{array}{l}\text { Purchase price : } 33,000 \\
\text { Marketing costs }: 3,600 \\
\text { Profits : } 1,400 \\
\text { Selling price: } 38,000\end{array}$ & 5,000 & \\
\hline 3. Retailer & $\begin{array}{l}\text { Purchase price : } 38,000 \\
\text { Marketing costs : } 2,000 \\
\text { Profit : } 5,000 \\
\text { Selling price: } 45,000\end{array}$ & 7,000 & \\
\hline Total marketing costs & & 5,600 & \\
\hline Total Profits & & 6,400 & \\
\hline Total Margin & & 12,000 & \\
\hline
\end{tabular}


From the table, there is a difference between the price paid by consumers and those paid by producers because in marketing carp not directly to consumers but using marketing channels. Where to get into the hands of consumers through traders, retailers, which causes marketing prices and profits from intermediary traders. The total marketing costs and profits from the intermediary traders are Rp. 5,600/ kg and Rp. 6,400 / kg so that it affects the price at the production level.

According to [7] the longer the trading system or the more institutions involved will cause the price received by producers to get smaller and show an inefficient marketing system.

Marketing margin is the difference between the price received by producers and the price paid by consumers, where the marketing margin is calculated based on the reduction in sales prices at each level of the marketing agency [10]. The difference in the margin in the marketing channel is determined by the length of the marketing channel, the number of marketing costs, and the profit expected by the marketing agency involved in the marketing agency's activities. The calculation of the marketing margin for gouramy in the Gajah Mina farmer group, Yeh Embang Kangin Village is shown in table 4. In the table, the marketing margin for collecting traders is Rp. 5,000 and retailers Rp. 7,000, so the total marketing margin for live gouramy is Rp. 12,000. However, if it is compared to the profit that the producers get compared to the overall margin value, it is higher, so it can be said that the marketing of gouramy produced by farmers in Yeh Embang Village is efficient. According to [9] the smaller the marketing costs, the more efficient the marketing. And marketing can be said to be efficient if the value received by farmers is greater than the overall marketing margin.

According to [3] marketing is said to be efficient if the marketed product can deliver results to consumers at low cost and a fair share of all costs paid to consumers to those who participate in the production and trading activities of the goods. From this discussion, it can be said that the marketing of gouramy caught by farmers in Yeh Embang Kangin Village is classified as efficient because the profits received by farmers are greater than the total marketing margin as a whole.

\subsection{Farmer Share}

Is a comparison of the price received by farmers with the price paid by consumers and expressed as a percentage (\%). Farmer share analysis is used to determine the results of the distribution of prices received by gouramy farmers with prices at the consumer level. Farmer share relates to marketing margins and has a negative relationship. Where if the marketing margin is lower, the farmer share received by the farmer is getting higher. Farmer's share of gouramy cultivation in Yeh Embang Kangin Village can be seen in Table 2. The marketing pattern used in marketing gouramy production in Yeh Embang Kangin Village, the farmer share is $73.3 \%$ with a marketing margin percentage of $26.6 \%$. Comparing the percentage of farmer share with marketing margin, marketing of gouramy is classified as efficient, because \% farmer share $>\%$ Marketing Margin [17] and according to [9], if the share received by farmers is greater than the share of marketing margin or the share received by farmers is close to $100 \%$, then the marketing channel is categorized as efficient.

\subsection{Marketing Efficiency Marketing}

Activities for fishery product commodities are not only the process of transferring products from producers to consumers, there are also other processes. These processes include collection, sorting, distribution, and including a selection of marketing channels. Where this process raises costs which are then calculated in the commodity price. The impact can increase prices to consumers and reduce prices at producers so that efficiency in marketing is necessary.

An efficient marketing system will encourage low marketing margins due to lower input costs from marketing activities. So that producer income increases. Prices are relatively cheaper for 
consumers and product competitiveness is higher. This will achieve fair profit sharing for the marketing agency actors. According to [3] marketing is said to be efficient if it meets 2 requirements, namely being able to deliver results to consumers at low cost, and being able to make a fair share of the total price paid by consumers to parties involved in the production and trading system of the goods.

The calculation of the marketing efficiency of gouramy in the Yeh Embang Kangin Village area, namely the total marketing cost divided by the consumer level price, obtained a marketing efficiency of $12.4 \%$. Thus, it can be said that the marketing of carp in the Yeh Embang Kangin area using a marketing channel involving intermediary traders can be said to be efficient because marketing efficiency is in the range of $0-33 \%$ [9].

\section{Conclusion}

Based on the discussion of the results of the study, it can be concluded as follows: There is a difference in the time and place of marketing between producers to consumers, so the marketing of gouramy produced in Yeh Embang Kangin is through intermediary traders with a marketing pattern, namely from producers to collectors to retailers than to consumers. Based on the calculation of the marketing margin, farmer's share, and marketing efficiency of the marketing channels used, the marketing margin is Rp. 12,000, farmer's share $73.3 \%$, and marketing efficiency $12.4 \%$. Where the farmer share is greater than the marketing margin and the marketing efficiency is in the range of 0$33 \%$, it is said that the marketing of live gouramy is still in the efficient category. The maintenance period for gouramy reaches a fairly long consumption size, namely 8-10 months, for that it is necessary to segment the enlargement so that the maintenance period is shorter, the farmer's income is faster and the production of gouramy to meet market needs is more continuous. developed in the region, especially those close to the marketing area and it is necessary to conduct post-harvest skills training for farmers so that marketing runs smoothly.

\section{References}

[1] Hasyim, A.I. (2012). Tataniaga Pertanian. Bandar Lampung: Universitas Lampung

[2] Eddiawan (1983). Peranan Koprasi dalam Pemasaran Hasil dan Pengembangan Desa Nelayan A. Dwiponggo (eds) Pusat Penelitian dan Pengembanagn Perikanan ; Jakarta.

[3] Mubyarto (2002). Pengantar Ekonomi Pertanian. Edisi ke 3. PT. Pustaka LP3ES.

[4] Kotler, Philip dan Amstrong G. (2001). Prinsip-prinsip Pemasaran. Jilid 2. Edisi Kedela pan. Terjemahan Damos Sihombing. Principles of Marketing, 8th Edition. 2001. Jakarta: Erlangga.

[5] Limbong WH dan P. Sitorus (1987). Pengantar Tata Niaga Pertanian. Bahan Kuliah Jurusan Ilmu-ilmu Ekonomi Pertanian. Fakultas Pertanian IPB.

[6] Ismail G. Supardi S. Dan Wahyuningsih, (2008). Analysis Efisiensi Marketing System of Fresh Laying Fish on Pelabuhan Fish Auction in Tegal City Jurnal Mediaagro. Volume IV (2) : $39-50$.

[7] Moehar M. (2002). Pengantar Ekonomi Pertanian. Cetakan Pertama. Jakarta: Bumi Aksara.

[8] Sugiono, (2014), Metode Penelitian Kuantitatif dan R \& D Alfabeta, Bandung.

[9] Riandi, R., Batubara, M. M., \& Iskandar, S. (2018). Analisis Efisiensi Pemasaran Udang Windu (Penaeus monodon) Di Desa Sungai Lumpur Kecamatan Cengal Kabupaten Ogan Komering Ilir. Societa: Jurnal Ilmu-Ilmu Agribisnis, 6(2), 81-87.

[10] Delia SC. (2017). Analisis Efisiensi Pemasaran dan Pendapatan Usaha Pengolahan Ikan Teri Asin di Pulau Pasaran Kota. Bandar Lampung. Departemen Ekonomi Sumber Daya dan Lingkungan. Fakultas Ekonomi Dan Manajemen (IPB).

[11] Guslan A, (2016). Analisis Strategi Saluran Pemasaran Usaha Budidaya Udang Windu Di Desa Pegat Batumbuk, Kecamatan Pulau Derawan Kaabupaten Berau. E-jurnal Administrasi Bisnis. 4 (4) : 975-989. 
[12] Wallong MC, Pontoh O, Rarung LK. (2015). Analisis Pemasaran Ikan Kerapu (Epinephelinae) di pasar Bersehati Kala Menado, Akulturasi Vo. 3 No. 6

[13] Soekartawi, (2002). Panduan Membuat Usaha Proyek Pertanian dan Pedesaan. Yogyakarta : PT. Bumi Aksara.

[14] Hanafiah dan AM Saefuddin (1986). Tata Niaga Hasil Perikanan. Universitas Indonesia Press. Jakarta

[15] Keegan KG, (2003). Manajemen Pemasaran Global, Jakarta : PT. Indeks Gramedia

[16] Hapsari. TD. (2013). Distribusi dan margin pemasaran Hasil Tangkapan Ikan Tongkol (Euthynus affinis) di TPI Ujung Batu Utara. Aqua Sain (Jurnal Ilmu Perikanan dan Sumber Daya Perairan) Vol. 2 : 132138.

[17] Abidin I, Harahap N, Asmarawati L. (2017). Pemasaran Hasil Perikanan. UB press 